\title{
Konsep Mandheg dalam Karawitan Gaya Surakarta
}

\author{
Ananto Sabdo Aji ${ }^{1}$ dan Suyoto \\ Institut Seni Indonesia Surakarta
}

\begin{abstract}
The Concept of Mandheg in Karawitan of Surakarta Style. This research reveals mandheg as one of the local concepts of Javanese music, especially the Surakarta style. Generally, some issues are explored in this research are related to the definition of mandheg and the process of mandheg itself. In more depth, this paper also discusses some point relating to the meaning, forming elements, and functions of mandheg in the process of gending work. These points are explained based on data on the presentation of a musical instrument as a factual data exploration media. The data collection was carried out by literature study, interviews, and also as a participant-observer. The analysis is carried out by reinterpreting the thoughts and experience of the pengrawit through practical reality. The interpretation uses the interpretation method and garap analysis. The explanation and getting conclusions are carried out by the inductive method. The mandheg is interpreted as a gendhing presentation that pauses at a point with the characteristic of the pattern of the kendhangan and the spesific flow after mandheg. The mandheg is divided into two, namely the mandheg kedah and mandheg pasrèn, with the elements of forming andhegan gawan, song sentences, balungan melodic variables, and sekar. The tend of mandheg are mandatory and facultative. Andhegan and specific variables make mandheg as forming a dynamic presentation.
\end{abstract}

Keywords: mandheg; gamelan jawa; pasrèn

\begin{abstract}
ABSTRAK
Tulisan ini mengungkap mandheg sebagai salah satu konsep lokal di dalam karawitan Jawa gaya Surakarta. Penelitian ini bertujuan untuk menggali persoalan yang terkait dengan pengertian mandheg, proses terjadinya mandheg, hal-hal yang berhubungan dengan pemaknaan, elemen pembentuk, dan fungsi mandheg di dalam proses penggarapan gending. Data dikumpulkan melalui studi pustaka, wawancara, dan pengamatan pertunjukan. Analisis dilakukan dengan menafsirkan kembali pemikiran dan pengalaman pengrawit yang diperoleh melalui realitas pragmatik. Berdasarkan penelitian disimpulkan bahwa mandheg dimaknai sebagai sajian gending yang berhenti sejenak pada sebuah titik dengan ciri pola kendangan mandheg dan alur yang spesifik setelah mandheg. Mandheg dibagi menjadi dua yaitu mandheg kedah dan mandheg pasrèn, dengan elemen pembentuk, antara lain andhegan gawan, kalimat lagu, variabel melodi balungan, dan sekar. Mandheg bersifat wajib dan fakultatif. Andhegan dan variabel yang spesifik membuat mandheg sebagai pembentuk sajian gending menjadi dinamis.
\end{abstract}

Kata kunci: mandheg; gamelan jawa; pasrèn

\section{Pendahuluan}

Mandheg menjadi hal yang sangat penting dan wajib untuk disajikan terutama gendinggending yang memiliki sajian andhegan. Mandheg dimaknai sebagai sajian gending yang digarap berhenti sejenak pada tempat tertentu, kemudian dilanjutkan kembali. Di dalam Kamus Basa Jawa (Bausastra Jawa) disebutkan bahwa, mandheg berarti lèrèn mari mlaku (Atmodjo, 1987). Hal ini dapat

1 Alamat korespondensi: Program Pascasarjana Pengkajian Seni Musik, ISI Surakarta. Jalan Ki Hadjar Dewantara No 19, Jebres, Kota Surakarta. E-mail: anantosabdoaji@yahoo.com. 
ditarik suatu pemahaman bahwa mandheg dalam kehidupan sehari-hari berarti berhenti sejenak dari suatu perjalanan jauh, kemudian perjalanan dilanjutkan kembali.

Pada hakikatnya mandheg dalam penyajian gending merupakan hal yang mutlak dan menjadi kebebasan pengrawit dalam menggarap sebuah gending. Meskipun penyajian mandheg bebas dilakukan, namun terdapat beberapa repertoar gending yang mempunyai ciri khas dengan didasari adanya andhegan gending. Gending yang memiliki andhegan khusus sebagai penciri gending menjadikan kehadiran mandheg sebagai hal yang wajib dilakukan. Mandheg memiliki kesamaan dan perbedaan dengan suwuk. Kesamaannya, mandheg dengan suwuk merupakan sama-sama sebuah peristiwa berhentinya sebuah sajian gending. Perbedaanya, suwuk merupakan berhentinya sebuah gending yang mencirikan bahwa sajian gending tersebut telah selesai dengan adanya sebuah tanda kendangan suwuk, sedangkan mandheg hanya berhenti sementara dalam sebuah sajian gending yang ditandai dengan ajakan instrumen kendang untuk berhenti sementara.

Dalam sajian karawitan, beberapa struktur gending dapat digarap mandheg, seperti pada mérong, inggah 4, inggah 8, ladrang, ketawang, ayak, lancaran, dan jineman. Mandheg dalam sajian karawitan yang sudah menjadi kebiasaan secara umum ada dua jenis mandheg, yaitu mandheg kedah (harus atau gending yang memang sudah dirancang untuk berhenti sementara pada bagian tertentu), dan mandheg pasren (yang bebas akan disajikan atau tidak). Secara lebih rinci lagi masih dapat dipetakan, kategori mandheg kedah meliputi: mandheg gawan dan mandheg kalimat lagu, kemudian yang masuk dalam kategori mandheg pasren meliputi: mandheg selingan dan mandheg varibel melodi balungan (boleh tidak mandheg). Mandheg digunakan sebagai tempat untuk ajang seorang pengrawit dan pesinden untuk menunjukkan kualitas keahliannya secara praktik dan garap. Mandheg juga dapat membangun kesan musikal menjadi lebih dinamis dan menarik, karena sajian menjadi tidak statis atau monoton.

Berdasarkan fakta musikal dalam penggarapan gending, dapat diketahui bahwa mandheg bukanlah tanda musikal yang bersifat fisik semata. Mandheg terkait erat dengan pengetahuan, keterampilan, dan rasa. Langkah menggali konsep musikal ini berdasarkan empirical practices, sebagai peristiwa musikal dalam karawitan Jawa yang didasari pada pengalaman empirik para empu/seniman karawitan (Hastanto, 2012). Konsep kebudayaan dapat didefinisikan sebagai keseluruhan cara bertingkah laku manusia dalam kehidupannya yang menjadi suatu identitas (Nursulistiyo, 2019). Hal tersebut secara keilmuan belum banyak mendapat perhatian. Selama ini masyarakat menyimpannya sebagai pengetahuan yang masih tersembunyi, akan tetapi tampak dalam ungkapan-ungkapan praktik karawitan. Pada sajian sebuah gending yang di dalamnya terdapat mandheg, pasti dalam proses terjadinya mandheg melalui berbagai pertimbangan dan faktor-faktor yang sangat penting untuk terciptanya mandheg. Sejauh ini setiap pengrawit melakukannya secara mengalir dan sudah menjadi kebiasaan para pengrawit. Faktafakta musikal di atas menunjukkan bahwa upaya pengungkapan konsep mandheg di dalam garap gending merupakan hal yang sangat penting untuk segera diinformasikan pemahamannya kepada masyarakat karawitan Sebagai contoh seorang pengendang akan menggarap mandheg tentunya melalui pertimbangan garap yang matang, karena garap mandheg tidak terlepas dari instrumen kendang dan vokal sindhèn di mana instrumen kendang menjadi faktor utama terjadinya mandheg, selanjutnya direspon oleh vokal sindhèn. Penyajian gending yang begitu kompleks membuat peran kendang menjadi vital sebagai pemimpin dalam sajian karawitan (Setyawan, 2018), hal tersebut juga diperkuat dengan pernyataan oleh Atmojo (Atmojo, 2010). Sifat musik gamelan adalah gotong royong, artinya garapan ricikan satu dengan yang lain saling mengisi, saling merespon, dan saling menginspirasi (Teguh, 2017). Tentunya tanpa elemen-elemen pembentuk mandheg yang benar maka sebuah sajian gending akan tidak menjadi sempurna dan terlihat terputus karena sulit untuk melanjutkan kembali setelah sajian mandheg. Sejauh ini masih banyak seorang pengendang yang masih bingung dalam menyikapi sebuah sajian gending untuk menentukan mandheg atau tidak. 


\section{Jenis Mandheg dalam Karawitan Gaya Surakarta}

\section{Mandheg Kedah}

Mandheg kedah artinya harus dilakukan mandheg dalam suatu sajian gending, sebab di dalam mandheg kedah terdapat sindhènan andhegan gawan yang kehadirannya sangat diperlukan yaitu sebagai penciri suatu gending. Kedah diartikan harus atau juga dapat diartikan wajib, mandheg kedah merupakan sebuah garap mandheg yang wajib dilakukan. Istilah kedah diambil dari istilah pada ricikan rebab yang terdapat istilah minir kedah dan minir pasrèn (Suraji, 2005), untuk memudahkan menyatukan sebuah persepsi maka digunakan istilah yang sudah ada dalam dunia karawitan. Dapat dikategorikan dalam mandheg kedah jika salah satu faktornya memiliki andhegan gawan. Mandheg kedah juga dapat disebut dengan mandheg gawan.

Gawan dari kata dasar gåwå yang artinya bawa, dalam konteks mandheg yang berarti bawaan dari sebuah gending. Artinya, mandheg gawan merupakan mandheg yang memiliki andhegan khusus dan hanya digunakan pada gending tertentu. Kata gawan mengambil dari istilah yang muncul dalam sindhènan, yang di dalamnya terdapat istilah sindhènan gawan gending. Istilah gawan juga terdapat pada sajian båwå, båwå gawan gending adalah ada keterkaitan antara båwå dengan gending, dengan memenuhi salah satu dari dua kriteria; (1) cakepan båwå menyebut nama gending sebagai dhawah-nya dan (2) ada kesamaan sebagian lagu båwå dengan susunan balungan gending (Suyoto, Timbul Haryono, 2015).

Sindhènan gawan gending adalah pola lagu (céngkok) sindhènan yang merupakan ciri khusus pada suatu gending yang cakepan (teks) dan pola lagu (céngkok) sindhènan melekat pada gendingnya serta tidak diterapkan pada bentuk gending yang lain. Sindhènan gawan céngkok merupakan pola lagu (céngkok) sindhènan yang disusun untuk nyindhèni struktur kalimat lagu balungan dan garap tertentu serta tidak dapat diterapkan pada struktur kalimat lagu dengan garap yang berbeda. Sindhènan gawan céngkok dapat diterapkan pada gending lain yang memiliki kasus yang sama (Suraji, 2005).
Mandheg kedah, berdasarkan faktor pendukungnya dibedakan menjadi dua, yaitu mandheg gawan gending yang terbentuk oleh andhegan gawan dan mandheg berdasarkan kalimat lagu.

\section{Mandheg Berdasarkan Gawan Gending}

Mandheg gawan gending adalah sebuah lagu atau gending yang membawa andhegan khusus dan memiliki faktor pembentuk yaitu andhegan gawan yang merupakan bagian yang tidak dapat dipisahkan dari gending itu sendiri, karena teks dan lagu andhegan gawan gending pada umumnya diambil dari sebagian lagu vokal dalam gending yang memiliki garap sindhènan gawan (Suraji, 2005). Sindhènan gawan merupakan jenis sindhènan yang cakepannya menyebut nama gending tertentu secara jelas atau lagu dan cakepannya telah menjadi satu kesatuan dengan gendingnya, sehingga tidak bisa digunakan pada gending yang lain (Suyoto, Timbul Haryono, 2015).

Andhegan gawan pada mandheg gawan gending dilakukan oleh vokal solo putri ketika sajian gending berhenti sementara dan lagu sindhènannya merupakan bagian dari gending itu sendiri serta tidak dapat disajikan pada gending lain (Suraji, 2005). Peran andhegan gawan pada sebuah sajian gending menjadi penciri dari gending itu sendiri, oleh karenanya struktur lagu andhegan gawan tersebut merupakan bagian yang tidak terpisahkan dari gending tersebut. Penerapan mandheg gawan gending wajib disajikan jika dalam gending terdapat andhegan gawan. Berikut contoh mandheg berdasarkan gawan gending.

Notasi inggah gendhing Budheng-budheng laras pélog pathet nem

$.5 .6 \cdot 5.6 \cdot 5.3 \cdot 1 . \hat{2}$

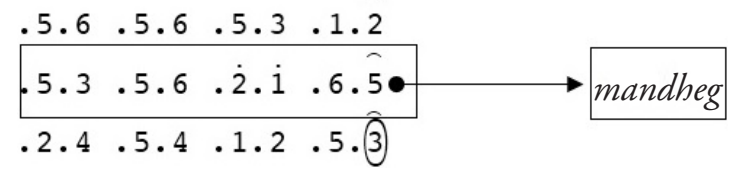

Notasi sindhènan andhegan arum-arum pada inggah gendhing Budheng-budheng

$5666, i \underbrace{2.3 i 2} \underbrace{6.53} \underbrace{5.6}$

We - ruh ma -nèh yèn we - ruh - $a$

$2 \quad 3556542 \quad 4 \quad 5.6545 .5$

nju-puk $\underbrace{\underbrace{}_{\text {la }}}_{\underline{a}-} \mathrm{du}-\underbrace{5.654}_{\mathrm{du}}$

6 i.2i6.i23 i2.i65 5,56 i 5,56 i 56.353 .2 .3 do-kok a - né hé hé hé hé hé hé hi yé 


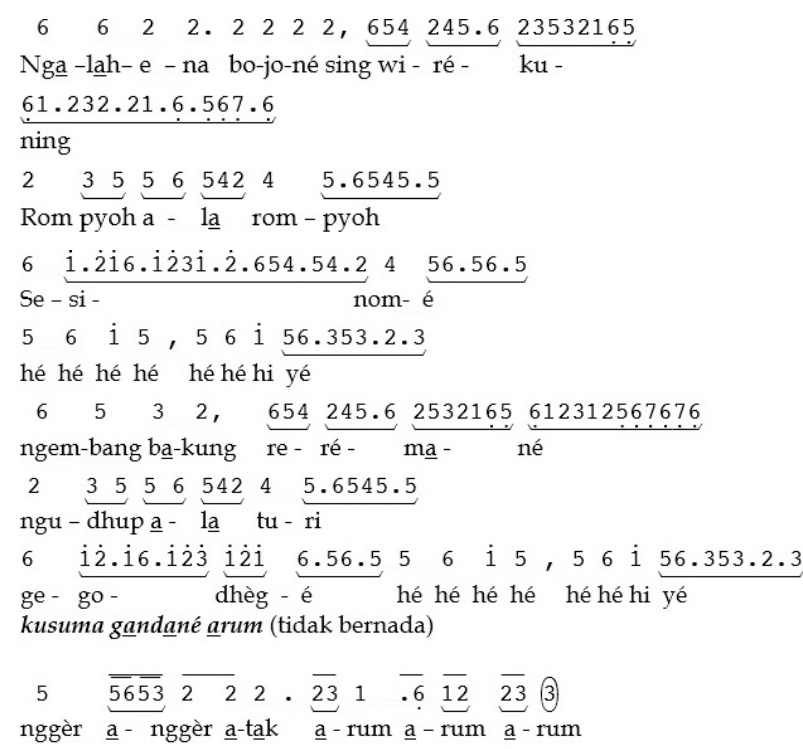

Gendhing budheng-budheng merupakan gending yang memiliki mandheg gawan gending, terbukti pada inggah terdapat mandheg terjadi pada kenong ke tiga dengan disertai sindhènan andhegan gawan. Andhegan gawan pada inggah budheng-budheng dirancang khusus hanya untuk gendhing budheng-budheng saja, oleh sebab itu dapat dikatakan andhegan gawan. Dalam andhegan berusaha menceritakan esensi pada gending Budheng-budheng, gending yang didasari tidak dari tembang atau sekar maka sulit menjelaskan isi dari gending tersebut. Tetapi dengan andhegan gawan dapat membantu menjelaskan makna dari sebuah gending.

Andhegan inggah budheng-budheng cukup panjang dan digunakan untuk merepresentasikan atau mewakili notasi balungan dari kenong ke tiga sampai gong. Namun dengan andhegan yang sangat panjang tersebut gending tidak terasa hilang atau terputus, justru kekuatan gending menjadi lebih kuat. Balungan gending yang hilang ketika mandheg sudah digantikan dengan andhegan yang dapat merepresentasikan balungan pada mandheg. Andhegan yang begitu panjang dan ekslusif membuat fokus dalam sajian gendingnya sangat dinanti kehadirannya. Kekuatan andhegan sangat kuat dalam penyajiannya, selain digunakan untuk menyempurnakan sajian gending, juga sebagai penciri dari gending budheng-budheng itu sendiri. Jika tidak disajikan mandheg pada inggah gending budheng-budheng maka belum dapat dikatakan gendhing budheng-budheng. Hal tersebut yang mendasari bahwa mandheg pada gendhing Budhengbudheng wajib dilakukan.

Letak mandheg pada mandheg gawan tidak bersifat normatif, dalam artian mandheg gawan memiliki letak mandheg yang abstrak dengan kreativitas pencipta gending masing-masing. Maka diperlukan pengetahuan empiris bagi seorang pengrawit untuk mengetahui letak andhegan gawan sebuah gending. Memang, musik dan aspek-aspek atau tingkah laku lainnya dalam kehidupan manusia memiliki keterkaitan, sehingga pemahaman mengenai suatu kebudayaan dapat dicapai antara lain lewat studi terhadap musiknya (Irawati, 2016). Sebagai contoh letak mandheg yang abstrak tidak semata untuk membedakan sebuah andhegan pada umumnya dengan andhegan gawan, tetapi hal tersebut didasari dengan pengetahuan garap yang tinggi.

Letak mandheg masih mempertimbangkan dua faktor, yaitu (1) faktor skema kendangan; dan (2) alur melodi sebelum dan sesudah mandheg. Faktor skema kendangan merupakan salah satu acuan pencipta gending menciptakan garap mandheg, letak mandheg pasti mempertimbangkan instrumen kendang dalam memberhentikan dan melanjutkan kembali sajian gending sesuai bentuk gendingnya. Faktor alur melodi juga menjadi faktor dalam pencipta gending meletakkan posisi mandheg, terbukti pada nada sèlèh pada letak mandheg tidak sekedar diposisikan pada nada tersebut namun nada sèlèh mandheg digunakan sebagai sebuah pijakan untuk vokal andhegan, serta alur melodi sebelum dan sesudah mandheg masih nyambung agar gending yang digarap mandheg dapat dilanjutkan kembali.

\section{Mandheg Berdasarkan Kalimat Lagu}

Mandheg berdasarkan kalimat lagu juga merupakan bagian dari mandheg kedah atau mandheg yang harus disajikan. Istilah kalimat lagu merujuk pada sebuah konfigurasi alur melodi vokal yang diciptakan secara struktural untuk mengharuskan digarap berhenti. Jadi faktor utama mandheg adalah dikarenakan terdapat kalimat lagu atau alur melodi yang lebih mengedepankan vokal yang dirangkai secara terstruktur dan sudah ditentukan untuk digarap mandheg. 
Kebanyakan dijumpai pada bentuk gending jineman dan bentuk gending lagon. Tidak semua jineman memiliki garap mandheg, tetapi mayoritas jineman terdapat garap mandheg, mandheg dalam jineman merupakan berdasarkan kalimat lagu yang sudah ditentukan. Begitu juga pada kasus lagon mayoritas garap mandheg berdasarkan faktor kalimat lagu vokal.

Mandheg berdasarkan kalimat lagu jika tidak disajikan atau digarap mandheg justru akan merusak sajian sebuah gending. Gending akan rusak atau tidak dapat dilanjutkan sajiannya jika dipaksakan untuk tidak berhenti, gending yang sudah dirancang mandheg berdasarkan kalimat lagu juga akan rusak strukturnya jika tidak disajikan mandheg. Mandheg kalimat lagu juga dapat dikatakan gawan gending, hanya faktor yang mempengaruhi berbeda. Jika pada mandheg berdasarkan gawan gending didukung dengan faktor andhegan gawan, sedangkan mandheg berdasarkan kalimat lagu merupakan mandheg dengan kalimat lagu vokal yang sudah diciptakan untuk mandheg pada bagian yang sudah ditentukan. Hal ini dapat dilihat dalam contoh pada kasus jineman Kreteg Ciyut laras sléndro pathet sanga.

Jineman Kreteg Ciyut laras sléndro pathet sanga Buka celuk:

\begin{tabular}{|c|c|c|c|c|c|c|c|c|}
\hline - & - & - & - & - & & $\begin{array}{c}5 \\
\text { Kre-t }\end{array}$ & $\begin{array}{l}\overline{6 \mathrm{i}} \\
\text { eg ci }-\mathrm{y}\end{array}$ & $\begin{array}{l}\dot{2} \dot{2} \\
\text { zut ra- }\end{array}$ \\
\hline$\dot{2} \dot{2}$ & $\overline{2 i}$ & $\overline{6 i \quad 5}$ & 2 & $\overline{23}$ & 5 & 3 & $\begin{array}{ll}21 & \overline{6}\end{array}$ & $\overline{65}$ \\
\hline da c & wa gro & bag lin & & ngul & er $\mathrm{k}$ & amba & Ing lakkur & \\
\hline 2 & 1 & 2 & . & 2 & & 1 & 6 & 5 \\
\hline $\begin{array}{ll}61 & 1\end{array}$ & 2 & . & . 5 & 6 & 1 & 2 & . & . 5 \\
\hline ka-re & g-kit & & $\underline{\mathrm{a}}$ & $-k \underline{a}$ & -rer & g-kit & & a- \\
\hline 2 & 1 & 2 & . & 2 & & 1 & 6 & (5) \\
\hline$\overline{61}$ & 2 & . & $\overline{.5}$ & 6 & $\overline{1}$ & 2 & & \\
\hline ka-re & g-kit & & $\underline{\mathrm{a}}-$ & ka-r & eng & -kit & & \\
\hline . & 6 & 1 & 2 & . & & 1 & 2 & 6 \\
\hline .5 & $6 . \overline{.1}$ & $\overline{1 . \overline{.2}}$ & $\overline{2.2}$ & 2 & 2 & $\overline{16}$ & $\overline{21}$ & 6 \\
\hline mon & tor & mon - & tor po & dho 1 & korn & nat ng & gé-ring-â & -a-ké \\
\hline 2 & 3 & 5 & . & 2 & & 2 & 6 & (1) \\
\hline$\overline{22}$ & 2 & $\overline{55}$ & 5 & 2 & 2 & 2 & $\overline{11}$ & 1 \\
\hline tut to & tut & tit tit & tit & tut & tut & tut $n$ & ngok ng & gok ngok \\
\hline 2 & 5 & 6 & 1 & 3 & & 2 & 1 & 6 \\
\hline . 2 & 56 & $\dot{1} \dot{2}$ & $6 i$ & . & 5 & 23 & $5 \mathrm{i}$ & 6 \\
\hline nggi & - & crangk & ringbra & atbrèt & t kes & na ke & - na ma & von \\
\hline . & 3 & 5 & 2 & 5 & & 3 & 2 & (1) \\
\hline . $\mathrm{i}$ & . 5 & 53 & 25 & . & 2 & 12 & 16 & 15 \\
\hline ning & gro & bag ku & 1-la ma & & $\underline{\mathrm{a}}$ & jeg & lon $\mathrm{m}$ & nawon $\underline{a}$ \\
\hline 6 & 1 & 2 & . & 2 & & 1 & 6 & 1 \\
\hline$\overline{61}$ & 2 & . & .5 & 6 & 1 & 2 & . & .5 \\
\hline ka-re & g-kit & & $\underline{\mathrm{a}}$ & - ka & -ren & g-kit & & a- \\
\hline
\end{tabular}

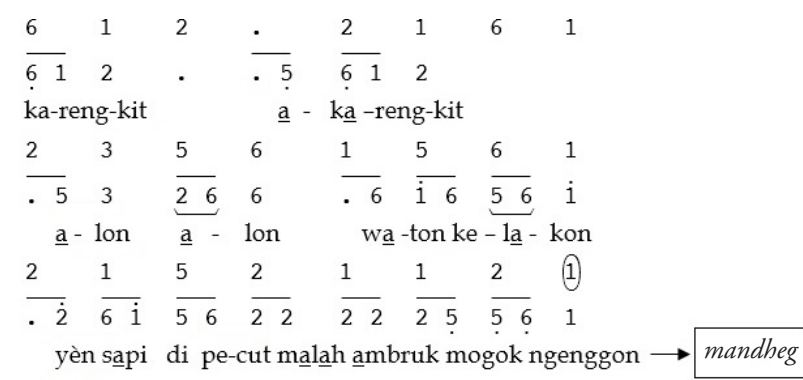

Celuk:

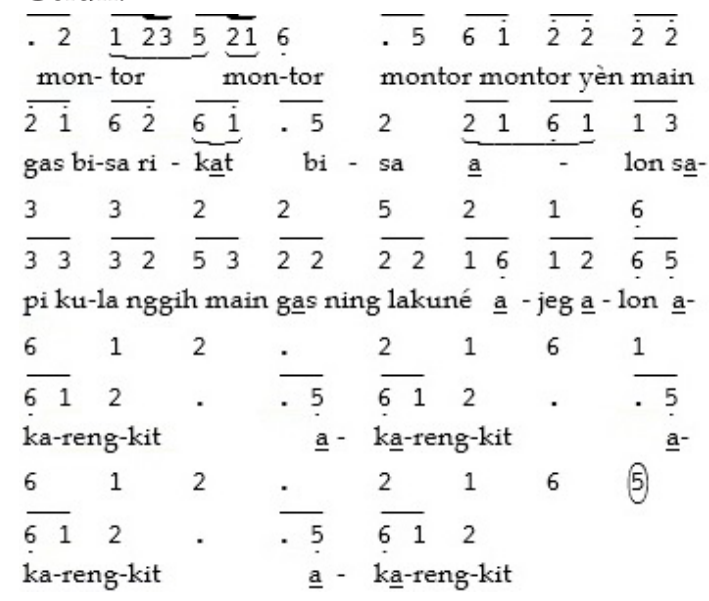

Mandheg pada jineman kreteg ciyut merupakan mandheg yang sudah diplot-plot atau sudah diatur alurnya untuk mandheg di beberapa tempat. Jineman wajib disajikan mandheg, jika tidak disajikan maka sajian tidak dapat dilanjutkan atau dapat rusak. Jineman kreteg ciyut memiliki garap spesifik atau garap beda setelah garap mandheg, oleh sebab itu jika sajian tetap diteruskan atau tidak digarap mandheg maka sajian gending tidak dapat dilanjutkan atau mengalami kerusakan sajian gending.

Mandheg berdasarkan kalimat lagu murni dari pencipta gending sudah diciptakan seperti itu, maka pengetahuan empiris sangat diperlukan dalam menyajikan gending dengan mandheg berdasarkan kalimat lagu yang terdapat pada struktur jineman. Tanpa sebelumnya mengetahui garap mandheg pada jineman yang akan disajikan, seorang pengrawit tidak dapat menyajikan sebuah gending dengan struktur jineman. Karena, tidak terdapat faktor lain yang dapat digunakan seorang pengrawit untuk menjadi sebuah acuan garap mandheg selain dengan faktor kalimat lagu khususnya pada garap jineman.

\section{Mandheg Pasrèn}

Pasrèn dari kata dasar asri yang berarti indah, jika dikorelasi dengan mandheg maka akan lebih 
indah atau sajian gending menjadi lebih dinamis jika digarap mandheg. Istilah pasrèn juga digunakan Hastanto dalam mengklasifikasikan ricikan gamelan yang disebut dengan ricikan pasrèn atau pepaès yang berarti hiasan (Hastanto, 2009). Pengertian tersebut dapat menguatkan istilah pasrèn dalam konteks mandheg sebagai garap yang tidak wajib disajikan namun kehadirannya menjadi sebuah hiasan atau memperindah sajian gending.

Pasrèn digunakan untuk menyamakan sebuah persepsi dalam garap mandheg, yang dapat diartikan boleh atau tidak disajikan. Mandheg pasrèn bersifat fakultatif, artinya sebuah garap mandheg yang tidak diwajibkan penyajiannya. Namun sajian gending akan lebih indah dan dinamis jika garap mandheg disajikan. Mandheg pasrèn tidak terikat dengan hal yang mewajibkan mandheg dari sisi musikal maupun teks atau cakepannya, sehingga jika tidak mandheg pada dasarnya tidak mempengaruhi sajian sebuah gending yang akan tetap dapat berjalan seperti semestinya. Mandheg yang termasuk dalam mandheg pasrèn dapat dikatakan sebagai varian garap dalam sebuah penyajian gending, dengan diperkuat andhegan yang disajikan oleh vokal sindhèn.

Mandheg pasrèn memiliki struktur yang normatif sesuai dengan bentuk gendingnya. Artinya, letak mandheg selalu sama sesuai dengan bentuk dan struktur gendingnya. Setiap struktur gending memiliki letak mandheg yang berbeda-beda, namun pada struktur yang sama dengan repertoar gending yang berbeda selalu memiliki letak mandheg yang sama. mandheg pasrèn didasari dengan faktor utama yaitu variabel melodi balungan, di mana susunan melodi balungan dalam sebuah gending menjadi penentu dapat digarap mandheg atau tidak. Mandheg pasrèn menggunakan andhegan yang dibangun berdasarkan alur melodi pada balungan mandheg atau dapat disebut dengan gawan céngkok.

\section{Mandheg Berdasarkan Variabel Melodi Balungan}

Mandheg variabel melodi balungan merupakan masuk dalam kategori mandheg pasrèn, di mana garap mandheg tersebut bersifat fakultatif atau tidak wajib tetapi kehadiran mandheg tersebut akan memberikan dampak dinamis pada sajian gendingnya. Mandheg berdasarkan variabel melodi balungan merupakan garap mandheg dengan faktor pembentuk variabel melodi atau susunan balungan yang juga disebut dengan céngkok. Tidak semua variabel melodi balungan dapat digarap mandheg, hanya céngkok-céngkok tertentu saja. Setiap menghadapi alur melodi atau céngkok yang memiliki alur dinamis maka sajian gending dapat digarap mandheg, dengan letak mandheg yang sudah konvensional menurut bentuk gendingnya. Dapat dilihat dalam contoh I pada kasus inggah gendhing Gambir Sawit laras sléndro pathet sanga.

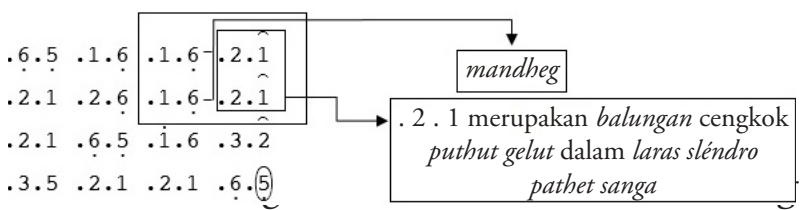

pada sturktur inggah 4, inggah gending Gambir Sawit memiliki mandheg pasrèn berdasarkan variabel melodi balungan. Pada kenong pertama dan kedua gåtrå ketiga dapat digarap mandheg dikarenakan varibel balungan setelahnya merupakan susunan balungan puthut gelut, yang di mana céngkok puthut gelut merupakan céngkok yang memiliki alur dinamis. Mandheg pada inggah gending Gambir Sawit tidak memiliki andhegan yang khusus atau gawan, oleh sebab itu andhegannya diisi dengan andhegan gawan céngkok. Mandheg tanpa adanya sebuah ikatan berupa faktor musikal maupun tekstual membuat mandheg bersifat faktultatif, namun sajian akan lebih menjadi dinamis jika garap mandheg disajikan. Hal yang sama juga terjadi dalam kasus inggah gendhing Banthèng Warèng laras sléndro pathet manyura.

\begin{tabular}{|c|c|c|c|}
\hline .3 .2 .3 .1 & $. 2 . 6 \longdiv { . 3 . 2 }$ & mandheg & . 3.2 merupakan balungan \\
\hline 3.2 .3 .1 & .2 .67 .5 .3 & & cengkok puthut gelut dalam \\
\hline $.5 .3 . \dot{2} . \dot{1}$ &.$\dot{2} \dot{i} \cdot \dot{2} \cdot \hat{6}$ & & sléndro pathet manyura \\
\hline .6 .3 .5 & $. \dot{1.6} . \dot{3} .2$ & Tidak ma & dheg \\
\hline
\end{tabular}

Kasus pada inggah gendhing Banthèng Warèng mandheg terjadi hanya pada kenong I saja, dikarenakan kenong pertama setelah mandheg dihadapkan dengan balungan yang memiliki alur dinamis yaitu céngkok puthut gelut, sedangkan pada kenong kedua tidak dapat digarap mandheg karena tidak menghadapi susunan balungan yang dinamis. Meskipun kenong dua dapat digarap mandheg, 
namun alur justru akan menjadi terputus dan tidak dapat nyambung, dikarenakan alur melodi setelah mandheg merupakan céngkok yang statis. Sama seperti pada kasus inggah Gambir Sawit andhegan yang digunakan merupakan gawan céngkok yang sudah ada diterapkan pada kasus mandheg inggah Banthèng Warèng. Dengan tidak disertai andhegan yang khusus maka mandheg bersifat tidak wajib disajikan.

\section{Mandheg Sekar}

Sekar merupakan puisi Jawa yang penyajiannya dilagukan menggunakan laras pélog dan sléndro dengan aturan tersendiri baik lagu maupun teks (Suyoto, 2016a). Sekar dikelompokkan menjadi tiga; (1) sekar ageng; (2) sekar tengahan; dan (3) sekar macapat (Suyoto, 2016a). Berdasarkan fungsinya sekar yang banyak diimplementasikan dalam sebuah gending adalah sekar macapat, sedangkan sekar ageng maupun sekar tengahan digunakan sebagai waosan, båwå, dan sulukan (Suyoto, 2016a). Sekar macapat merupakan unsur di dalam sebuah sindhènan (Budiarti, 2013).

Mandheg sekar merupakan garap mandheg yang terbentuk dengan faktor sebuah tembang macapat yang digunakan di dalam gending, seperti misalnya: Ladrang Pangkur, menggunakan cakepan tembang Pangkur. Ketawang Sinom, menggunakan cakepan tembang Sinom, Ketawang Mijil, menggunakan cakepan tembang Mijil. Gending-gending yang terbentuk dengan tembang macapat biasanya digunakan untuk keperluan tertentu misalnya beksan langendriyan, kethoprak, dan lain sebagainya. Sebagai sebuah sajian vokal, memiliki dua unsur yang saling terkait yakni lagu dan cakepan (Rahayu, 2018). Tembang merupakan puisi Jawa yang penyajiannya dengan cara dilagukan dan menggunakan laras sléndro dan pélog (Suyoto, 2016 b).

Gending yang dibentuk dari tembang macapat selalu terdapat lagu sindhènan pokok yang berasal dari lagu tembang macapat yang menjadi dasar pembentuknya (Sugimin, 2005). Tembang yang ditulis dalam bentuk teks merupakan media berpikir dan merasa, merupakan media komunikasi estetik (Darmasti, 2011). Lagu sindhènan memiliki alur yang khusus dan spesifik, dengan céngkok lagu yang spesifik dapat digarap mandheg di mana saja tanpa mempertimbangkan variabel melodi balungan, hanya mempertimbangkan gåtrå dalam tembang macapat yang digunakan. Alur yang spesifik membuat mandheg lebih fleksibel, karena setelah mandheg mudah untuk melanjutkan kembali dengan céngkok tembang yang sudah spesifik pada sekar macapat. Dapat dilihat pada kasus Ladrang Pangkur laras sléndro pathet sanga berikut.

Ladrang Pangkur laras sléndro pathet sanga bagian irama wiled

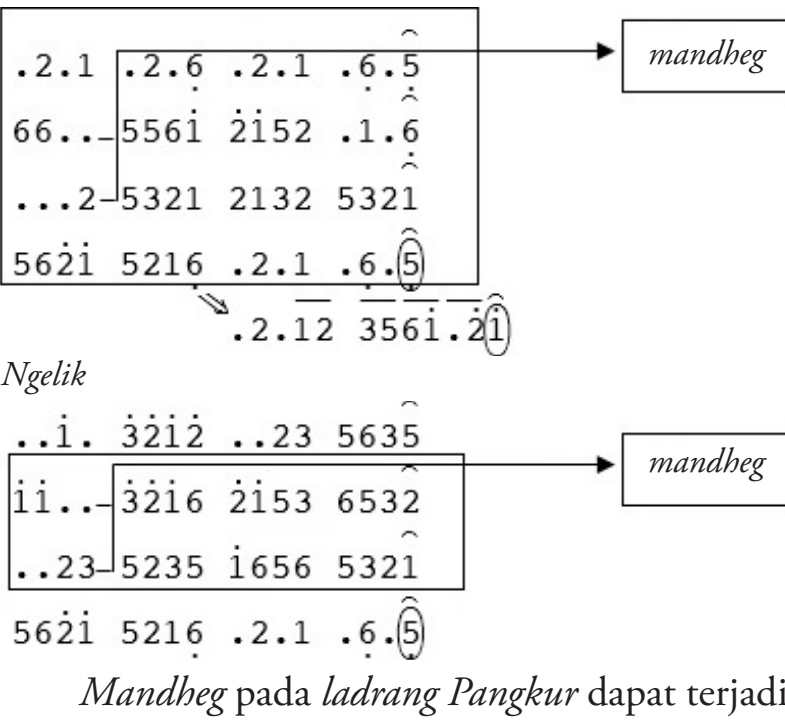
di mana saja dengan mempertimbangkan kalimat lagu tembang Pangkur yang digunakan, tetapi pada garap secara konvensional mandheg terletak pada gåtrå pertama kenong I-III bagian irama wiled dan gåtrå pertama kenong kedua dan ketiga bagian ngelik. Sebuah gending sangat fleksibel, dapat mengalami pemanjangan dan pemendekan waktu atau yang disebut dengan mulur-mungkret (Budi Prasetya, 2012). Bagian ngelik tersebut sudah ada sejak zaman Paku Buwana X yang dipinjam dari bagian ngelik ladrang Kasmaran (Eling-eling) (Sugimin, 2013). Tembang Pangkur yang melekat pada ladrang Pangkur sudah memiliki céngkok atau alur lagu yang spesifik setiap barisnya, sehingga garap mandheg dapat diterapkan di mana saja, namun tetap mempertimbangkan kalimat lagu pada tembang Pangkur. Kalimat lagu yang spesifik memudahkan seorang pesinden untuk memulai kembali ketika digarap mandheg, hanya melanjutkan alur yang terhenti sejenak. Meskipun faktor alur melodi pada tembang menjadi faktor utama dalam menentukan mandheg, terkadang juga secara kebetulan atau tidak bersamaan dengan variabel melodi bal- 
ungan yang memiliki alur dinamis. Dasar tersebut juga berlaku pada jenis gending sekar yang lain.

\section{Konsep Mandheg}

Berangkat dari pengertian mandheg sebagai sajian gending yang digarap berhenti sementara pada titik tertentu, maka untuk mengerti konsep penyajiannya harus mengetahui faktor yang mempengaruhi mandheg dalam sebuah penyajian gending. Seorang pengendang tanpa mengetahui faktor penyebab mandheg dapat menyebabkan sajian gending rusak atau bahkan tidak dapat dilanjutkan kembali.

Penerapan mandheg dalam sajian gending menjadi bagian yang sangat penting, karena jika mandheg diterapkan dengan benar, maka sajian gending menjadi lebih dinamis dan lebih sempurna. Setiap gending memiliki penerapan mandheg masing-masing. Ricikan yang dapat menggarap sajian gending mandheg adalah kendang, oleh karena itu seorang pengendang harus mempertimbangkan mandheg berdasarkan

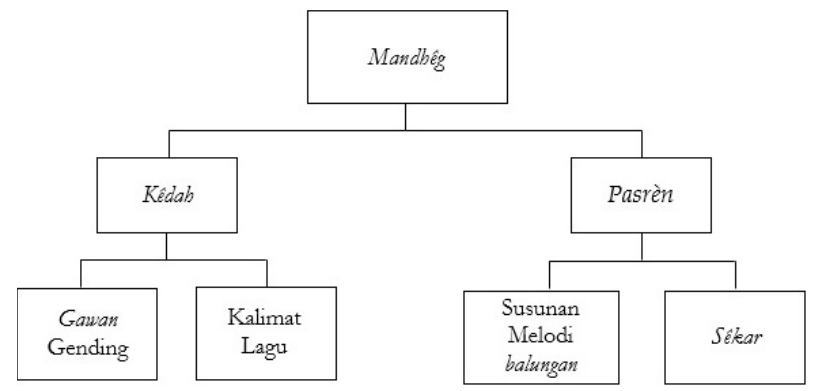

Diagram 1. Jenis-jenis mandheg oleh Ananto Sabdo Aji, 2018.

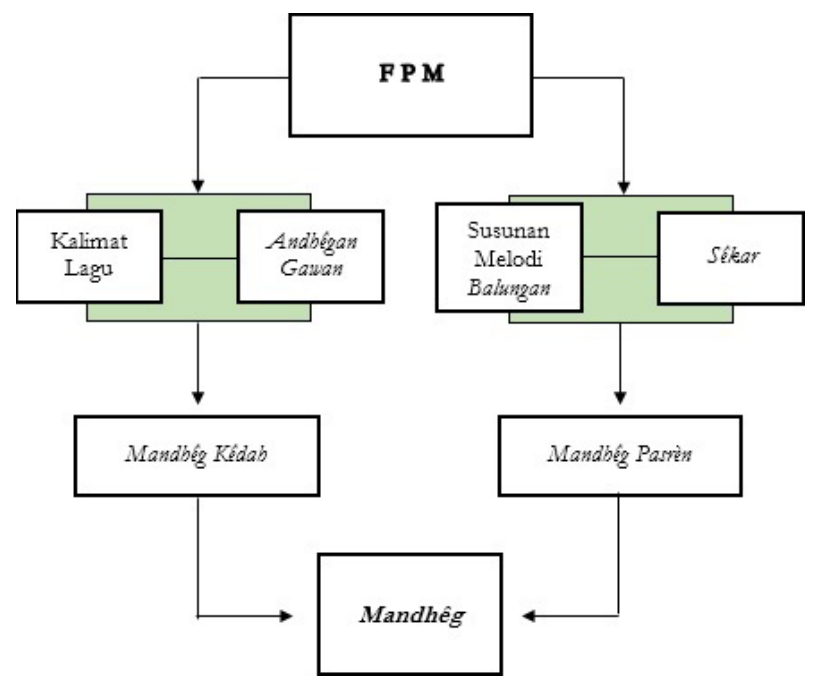

Bagan 1. Faktor Pembentuk Mandheg (FPM) oleh Ananto Sabdo Aji, 2018. garap musikal, juga harus mempertimbangkan faktor karakter seorang pesindhèn dan situasi ketika pementasan untuk menjaga keutuhan penyajian sebuah gending (Purnomo, 29 November 2018).

Pemaparan faktor pembentuk mandheg (selanjutnya ditulis FPM) dalam sebuah gending terlihat beberapa aspek musikal yang saling terkait. Terdapat tiga aspek FPM; yaitu (1) andhegan gawan, (2) kalimat lagu vokal, dan (3) variabel melodi balungan. FPM dengan andhegan gawan dan alur lagu digunakan pada mandheg kedah yang wajib disajikan, sedangkan FPM dengan variabel melodi balungan digunakan pada mandheg yang bersifat fakultatif atau pasrèn. Seorang pengendang pertama harus dapat menentukan unsur musikal apa yang dapat menentukan mandheg, kemudian letak atau posisi mandheg pada sebuah gending. Untuk dapat menjelaskan lebih mendalam maka diperlukan analisis yang lebih mendalam. Berikut adalah contoh gending beserta faktor pembentuknya.

\section{Faktor Pembentuk Mandheg Berdasarkan Andhegan Gawan}

Andhegan gawan adalah sebuah lagu yang diciptakan khusus oleh pencipta gending untuk

Tabel 1. Contoh gending beserta faktor pembentuknya.

\begin{tabular}{|c|c|c|}
\hline Gending & $\begin{array}{c}\text { Faktor } \\
\text { Pembentuk }\end{array}$ & Potensi \\
\hline Jangkung Kuning & andhegan gawan & wajib disajikan \\
\hline Budheng-budheng & andhegan gawan & wajib disajikan \\
\hline Kuwung-kuwung & andhegan gawan & wajib disajikan \\
\hline $\begin{array}{l}\text { Jineman Glathik } \\
\text { Glinding }\end{array}$ & kalimat lagu & wajib disajikan \\
\hline Jineman Gendra & kalimat lagu & wajib disajikan \\
\hline $\begin{array}{l}\text { Jineman Kreteg } \\
\text { Ciyut }\end{array}$ & kalimat lagu & wajib disajikan \\
\hline \multirow[t]{2}{*}{ Gambir Sawit } & $\begin{array}{l}\text { variabel melodi } \\
\text { balungan }\end{array}$ & $\begin{array}{l}\text { boleh/tidak } \\
\text { disajikan }\end{array}$ \\
\hline & $\begin{array}{l}\text { variabel melodi } \\
\text { balungan }\end{array}$ & $\begin{array}{l}\text { boleh/tidak } \\
\text { disajikan }\end{array}$ \\
\hline Onang-onang & andhegan gawan & wajib disajikan \\
\hline \multirow[t]{2}{*}{ Lambangsari } & $\begin{array}{l}\text { variabel melodi } \\
\text { balungan }\end{array}$ & $\begin{array}{l}\text { boleh/tidak } \\
\text { disajikan }\end{array}$ \\
\hline & $\begin{array}{l}\text { andhegan gawan } \\
\text { pamijen }\end{array}$ & wajib disajikan \\
\hline Widasari & $\begin{array}{l}\text { variabel melodi } \\
\text { balungan }\end{array}$ & $\begin{array}{l}\text { boleh/tidak } \\
\text { disajikan }\end{array}$ \\
\hline
\end{tabular}


menegaskan isi dari gending tersebut, maka kehadiran andhegan gawan sangat penting untuk memberikan sebuah penegasan dan ciri khas atau sebuah identitas pada gending. Andhegan gawan bersifat eksklusif, artinya hanya dapat digunakan pada gending bawaannya, maka dikatakan andhegan gawan yang berarti andhegan bawaan. Kedudukan, peran, dan fungsi sindhènan di dalam karawitan tidak dapat dikesampingkan (Saraswati, 2013).

Pengendang dapat menggunakan andhegan gawan sebagai acuan untuk menggarap mandheg. Tidak cukup hanya mengerti andhegan mandheg saja, melainkan letak atau posisi mandheg juga harus dimengerti oleh seorang pengendang. Letak mandheg pada andhegan gawan bersifat tidak normatif atau abstrak. Artinya, letak mandheg tidak bersifat konvensional melainkan bebas sesuai dengan pencipta gendingnya. Posisi mandheg dapat terjadi di mana saja, oleh karena itu FPM berdasarkan andhegan gawan tidak cukup dengan andhegan gawan saja melainkan beserta letak atau posisinya. Posisi mandheg pada andhegan gawan tidak terdapat acuan secara musikal untuk seorang pengendang dan dibutuhkan pengetahuan empiris sebelumnya dalam menentukan letak mandheg. Tanpa adanya pengetahuan empiris sebelumnya maka seorang pengendang tidak dapat memberhentikan sementara sebuah sajian gending.

Posisi mandheg bersifat bebas sesuai kreativitas pengarang gending. Maka pengetahuan empiris seorang pengendang merupakan faktor utama untuk mengetahui posisi mandheg pada gending yang memiliki andhegan gawan. Jika seorang pengendang tidak memiliki pengetahuan empiris mengenai posisi mandheg pada mandheg gawan, maka seorang pengendang harus menganalisis secara alur melodi andhegan gawan dengan susunan melodi balungan pada gending, hal tersebut setidaknya membantu seorang pengendang untuk menentukan di mana posisi mandheg. Berikut analisis mengenai penentuan letak mandheg.

Notasi inggah gending Kuwung-kuwung laras pélog pathet barang

$.2 .7 \cdot 2.3 \cdot 7.6 \cdot 2 . \overline{7}$

$\begin{array}{llll}.2 .7 & .2 .3 \quad .7 .6 \quad .2 .7\end{array}$

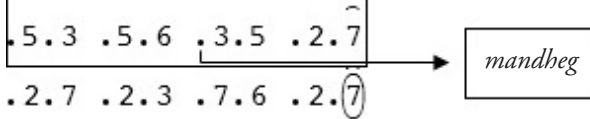

Notasi sindhènan andhegan inggah gending Kuwung-kuwung laras pélog pathet barang

$\begin{array}{llllllllllllll}3 & 6 & 3 & 6 & 7 & 2, & 2 & 7 & 2 & 3 & 2 & 7, & 6.5327 & 6.5\end{array}$ Kem-bang kem-bang ni-pahh su-me-bar te-ngah-ing $\underbrace{}_{\text {sa }}$ - wah padang ulihan

Dilihat berdasarkan andhegan gawan pada Gendhing Kuwung-kuwung di atas memiliki dua frase, setiap satu frase memiliki padang dan ulihan, setiap padang maupun ulihan memiliki sèlèh nada. Frasa pertama memiliki sèlèh@dan 5, sedangkan frasa kedua memiliki sèlèh 2 dan 7 dengan tanda kenong pada nada 7. Maka dapat kita lihat pada notasi gending yang memiliki sèlèh sama dengan andhegan pada bagian mana. Dengan melihat sèlèh andhegan dan notasi balungan gending, maka yang mendekati adalah bagian menjelang kenong ketiga. . $5 \cdot 3 \cdot 5 \cdot 6 \frac{.3 \cdot 5}{\text { padang }} \cdot \frac{2 \cdot \overline{7}}{\text { ulihan }}$

Dua gåtrå menjelang kenong ketiga memiliki sèlèh yang sangat mendekati pada andhegan gawan gending. Maka seorang pengendang setidaknya dapat menafsirkan bahwa mandheg terletak di sekitar dua gåtrå menjelang kenong. Tepatnya pada bagian sabetan gåtrå berapa sulit untuk dapat di identifikasi, olehkarena itu faktor empiris pengrawit sangat dominan dalam hal menentukan mandheg.

Cara untuk menafsirkan seorang pengendang mengetahui letak mandheg di atas tidak dapat dipakai secara umum dalam melihat letak mandheg pada kasus andhegan gawan. Di dalam karawitan secara lisan memiliki potensi reinterpretasi (Subuh, 2016). Setiap gending tidak memiliki kasus yang sama dengan contoh di atas, namun hal tersebut dapat digunakan sebagai langkah alternatif jika seorang pengendang tidak mengerti letak mandheg. Faktor utama dalam penyajian mandheg gawan adalah andhegan gawan. Setiap gending yang memiliki andhegan gawan wajib bagi seorang pengendang untuk menyajikan mandheg. Andhegan gawan menjadi satu kesatuan musikal dalam sajian gending untuk mencapai kesempurnaan.

\section{Faktor Pembentuk Mandheg Berdasarkan Kalimat Lagu Vokal}

Kalimat lagu vokal yang dimaksud adalah sebuah alur lagu vokal yang diciptakan memiliki 
alur lagu yang spesifik. Lagu merupakan susunan nada-nada yang sudah diatur dan apabila dibunyikan sudah terdengar enak (Martopangrawit, 1969). Lagu dalam penyajian gending tidak selalu berbentuk nyanyian, akan tetapi dapat berupa (1) balungan gending dan (2) konfigurasi musikal (Lestariningsih, 2016). Wujud dari balungan gending secara konkret tersusun melalui gåtrå dengan alur tertentu, jadi balungan gending itu sendiri merupakan lagu yang memiliki alur tertentu. Tanpa disertai vokal, alur lagu balungan dapat dirasakan. Vokal merupakan bagian yang berkaitan erat de-ngan kualitas seni karawitan (Budiarti, 2013). Konfigurasi musikal berupa sebuah céngkok yang dibawakan atau dihasilkan oleh ricikan garap dan/atau céngkok dalam sindenan juga memiliki alur lagu tertentu. Namun, pada kasus alur lagu vokal ini terfokus pada alur lagu yang melekat pada sebuah vokal, seperti contoh dibawah ini.

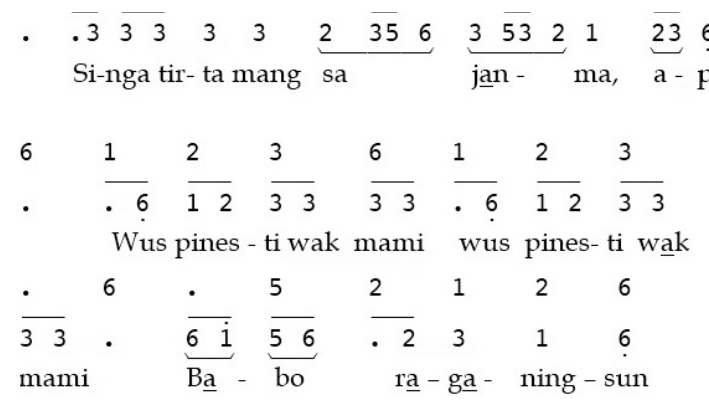

Alur melodi balungan tidak akan merubah melodi vokal, sehingga tanpa adanya melodi balungan kalimat lagu tetap dapat berdiri secara mandiri. Melodi vokal menjadi kekuatan sebuah alur pada gending tersebut. Kasus pada FPM berdasarkan andhegan dan FPM berdasarkan kalimat lagu merupakan kasus yang sama, karena mandheg pada kedua kasus tersebut mutlak diciptakan khusus oleh pencipta gending untuk harus mandheg pada titik tertentu.

Meskipun mandheg berdasarkan andhegan dan kalimat lagu merupakan sama-sama mandheg yang wajib disajikan, namun terdapat perbedaan yang signifikan. Pada dasarnya mandheg gawan jika tidak disajikan maka sajian akan tetap dapat berjalan dengan baik sampai selesai, meskipun sajian tidak sempurna secara garap. Sajian gending dengan FPM kalimat lagu akan rusak jika mandheg tidak disajikan, karena vokal merupakan titik tumpu pada sajian mandheg kalimat lagu. Gending tidak dapat dilanjutkan jika garap mandheg tidak sesuai dengan kalimat lagu yang sudah ditentukan.

Faktor utama yang mempengaruhi mandheg dalam mandheg kalimat lagu adalah mutlak dari pengarang gending. Lagu diciptakan dengan frase-frase tertentu sesuai kreativitas pengarang gending, tidak terdapat acuan secara musikal untuk seorang pengendang dalam menyajikan gending tersebut. Pengetahuan empiris sangat dibutuhkan dalam menyajikan gending dengan FPM kalimat lagu, tanpa adanya pengetahuan sebelumnya maka seorang pengendang tidak dapat menyajian gending-gending dengan FPM kalimat lagu.

Mandheg berdasarkan kalimat lagu tidak memiliki sebuah andhegan, setelah mandheg vokal sindhèn menyajikan lagu yang berikutnya. Pada kasus tertentu kalimat lagu setelah mandheg memiliki garap yang berbeda dari sebelumnya. Hal tersebut juga menjadi salah satu faktor mandheg wajib disajikan.

\section{Faktor Pembentuk Mandheg Berdasarkan Variabel Melodi Balungan}

Variabel melodi merupakan susunan melodi balungan pada sebuah gending yang dapat digunakan sebagai acuan seorang pengendang untuk menggarap mandheg. Mayoritas mandheg terjadi pada susunan melodi balungan yang memiliki garap puthut gelut, selain itu juga terdapat pada variabel dengan céngkok nduduk, kacaryan, ora butuh dan lainnya. FPM variabel melodi balungan juga memiliki posisi mandheg yang sudah bersifat konvensional pada setiap struktur gendingnya.

Dalam sebuah gending setiap variabel melodi balungan memiliki tafsiran céngkok pada setiap instrumen garap. Céngkok di dalam gending memiliki dua pengertian: (1) céngkok yang berarti garap; dan (2) céngkok yang berarti jumlah gong pada suatu gending (Martopangrawit, 1969). Céngkok dalam arti garap adalah suatu lagu yang permanen baik vokal maupun instrumen gamelan, sedangkan céngkok yang berarti jumlah gongan pada gending dipakai untuk penyebutak struktur gending dalam penyajian gending, dalam contoh untuk penyebutan gending yang memiliki struktur 
"mérong satu céngkok" dan "inggah satu céngkok" satu céngkok yang dimaksud adalah satu gongan. Dalam konteks penelitian ini céngkok yang berarti garap.

Seorang pengendang diwajibkan mengetahui variabel-variabel bagaimana yang dapat digarap mandheg dan tidak. Untuk itu diperlukan analisis mengenai céngkok untuk mengetahui landasan mandheg dengan variabel melodi balungan. Secara umum FPM variabel melodi balungan menjadi pusat acuan garap mandheg. Kasus mandheg gawan juga ada yang keterkaitan dengan variabel melodi, jadi tidak semata-mata karena andhegan gawan melainkan juga terpengaruh dengan variabel balungan untuk membuat céngkok andhegan. Untuk mengetahui dasar mandheg pada FPM variabel maka dibutuhkan analisis terhadap variabel melodi balungan atau céngkok.

Analisis kali ini céngkok akan diklasifikasikan berdasarkan alur melodinya yang dibagi menjadi tiga alur yaitu céngkok dengan alur statis/flat, semi statis, dan dinamis. Pembentukan dinamika garap dibangun dengan penggarapan sajian gending oleh ricikan garap, salah satunya penggarapan pada céngkok. Setiap karakter céngkok memiliki kontribusi terhadap garap sajian gending, dapat membuat gending menjadi dinamis atau gending dengan menjadi flat.

\section{Céngkok Dinamis}

Dinamis merupakan sesuatu yang memiliki pergerakan atau perubahan. Istilah dinamis dipinjam untuk memaknai sebuah alur yang memiliki pergerakan atau perubahan terhadap kontur melodi. Céngkok dinamis merupakan sebuah istilah yang digunakan untuk menyebut céngkok yang memiliki alur melodi dengan perubahan kontur sangat signifikan. Alur melodi pada céngkok dinamis setidaknya memiliki empat tingkatan perubahan nada. Alur yang dinamis di dalam sebuah céngkok menjadikan garap pada céngkok tesebut memiliki spesifik garap atau kekhususan garap seperti contoh berikut.

Céngkok Puthut Gelut laras slendro pathet manyura

$33.6532 \longrightarrow$ notasi balungan

$.356 .66 \dot{1} .3216122 \longrightarrow$ tafsir rebaban

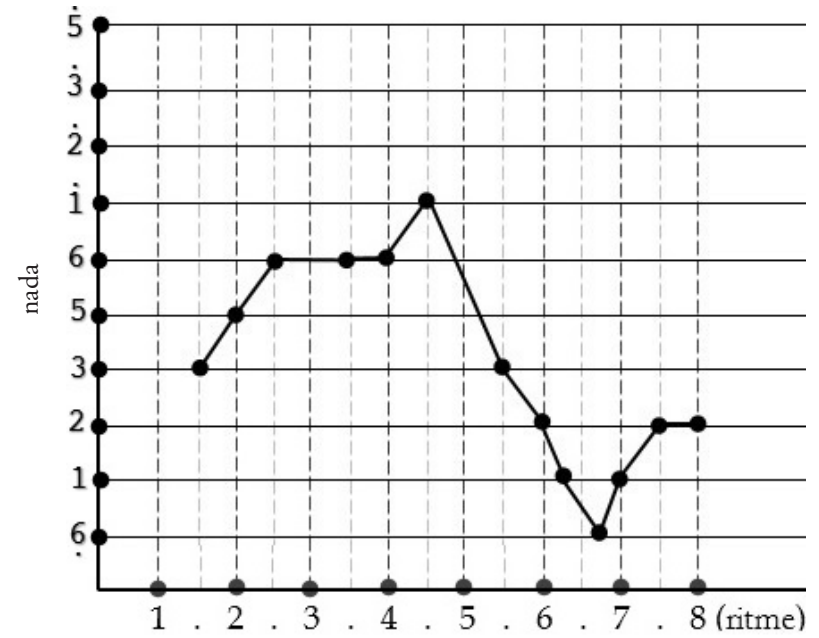

Grafik 1. Alur melodi céngkok Puthut Gelut.

Céngkok Ayu Kuning laras sléndro pathet manyura

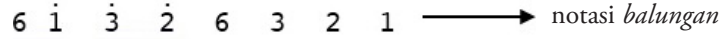

$\overline{.6} \overline{12} \overline{3} \overline{3.52} \overline{\overline{3} 1 \overline{26}} \overline{21121} \longrightarrow$ tafsir rebaban

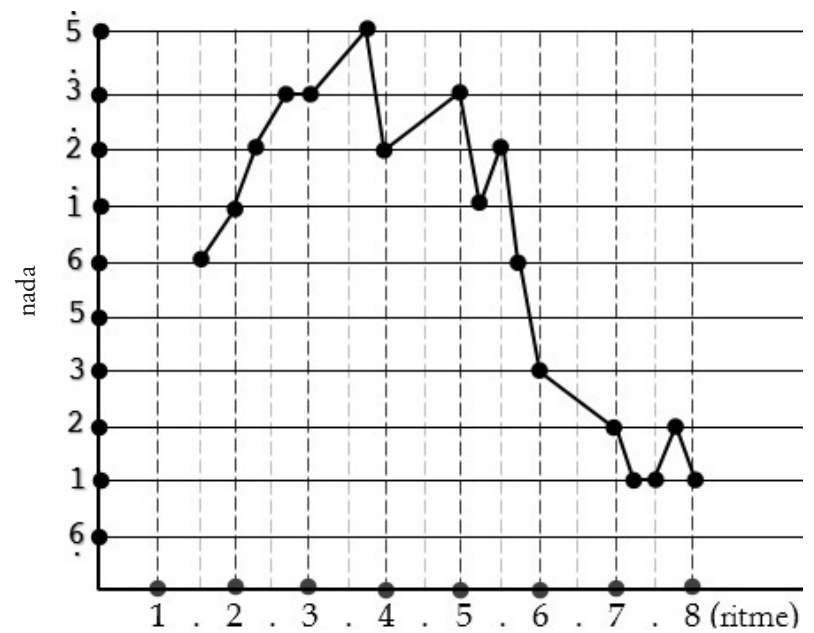

Grafik 2. Alur melodi céngkok Ayu Kuning.

Céngkok Nduduk laras sléndro pathet manyura

3 2 i $6 \longrightarrow$ notasi balungan

$\overline{56} \overline{6 i} 6 \overline{i 2} \dot{3} \cdot \bar{i} \dot{i} \overline{6} \longrightarrow$ tafsir rebaban

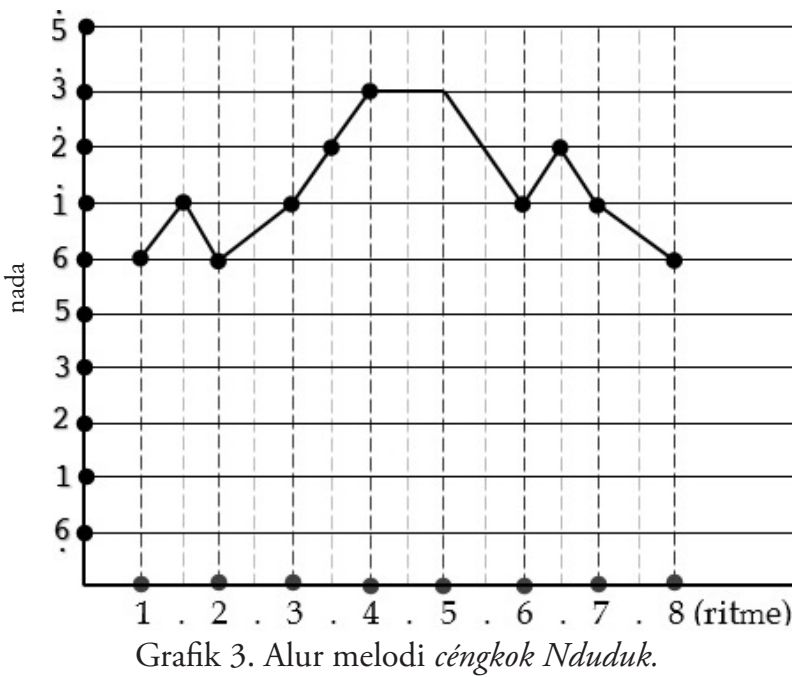


Contoh di atas merupakan céngkok yang memiliki alur melodi dinamis, dengan minimal empat tingkatan alur nada. Pada kasus gendinggending yang sudah ada, mandheg terjadi di céngkok-céngkok di atas, hal tersebut menegaskan bahwa céngkok yang dinamis dijadikan acuan dasar seorang pengendang untuk menggarap mandheg pada sebuah gending. Alur céngkok yang dinamis secara garap musikal membuat gending menjadi dinamis. Dinamis yang dimaksud adalah dinamis secara garap musikal, yaitu sebuah gending yang memiliki susunan melodi balungan dengan céngkok dinamis maka dapat disebut dinamis secara garap. Berbeda dengan dinamis secara teknik yang diartikan sebagai keras-lirihnya tabuhannya dan cepat-lambatnya laya pada sajian gending.

Garap yang dinamis salah satunya dalam garap céngkok sangat berperan dalam membangun suasana gending (Supanggah, 2009). Dinamis tidak hanya cenderung pada garap instrumental yang ritmis, cepat, menonjolkan volume, dan penonjolan ricikan. Secara umum, dalam karawitan memiliki unsur nada, notasi, irama, lagu, teknik, dan ritme (Surya Osada, 2015). Ritmis merupakan salah satu aspek musikologis yang berhubungan dengan sifat musikalitas (Yasa, 2017). Dinamis juga terdapat di dalam garap gending, céngkok yang dinamis tentunya sangat berperan dalam membangun dinamika sajian gending.

Alur yang dinamis membuat garap mandheg memiliki kekuatan dinamika tersendiri yang mengakibatkan sajian gending akan menjadi lebih hidup. Secara fisika, ketika pengrawit memainkan gamelan, mereka memindahkan energi kinetik dari tubuhnya pada instrumen gamelan (Prasetya, Haryono, \& Simatupang, 2016). Hal tersebut menjadi sebuah landasan bahwa mandheg dengan variabel melodi balungan dapat disajikan ketika menghadapi susunan melodi balungan yang memiliki alur dinamis. Tentunya dengan struktur gending yang sudah konvensional.

\section{Céngkok Semi Statis}

Céngkok semi statis adalah céngkok yang juga memiliki alur yang dinamis tetapi tidak signifikan, kontur melodinya tidak lebih dari tiga tingkatan nada, Alur yang dihasilkan cenderung datar, maka dapat dikatakan semi statis. Dalam penggarapannya céngkok semi statis dapat berubah menjadi dinamis, namun hanya sebatas dinamis dalam penafsiran garap, esensi dari céngkoknya tetap bersifat semi statis. Berikut analisis kontur melodi pada céngkok yang memiliki alur semi statis.

Pada dasarnya setiap céngkok dapat digarap mandheg, namun secara konvensional tidak lazim disajikan. Begitu dengan céngkok semi statis jika digarap mandheg maka sah-sah saja, namun secara sajian karawitan gaya Surakarta yang sudah berlaku sampai sekarang hal tersebut belum pernah

Céngkok Jarik Kawung laras sléndro pathet manyura

$1312 \longrightarrow$ notasi balungan

$\overline{13} 3 \cdot \overline{23} 22 \longrightarrow$ tafsir rebaban

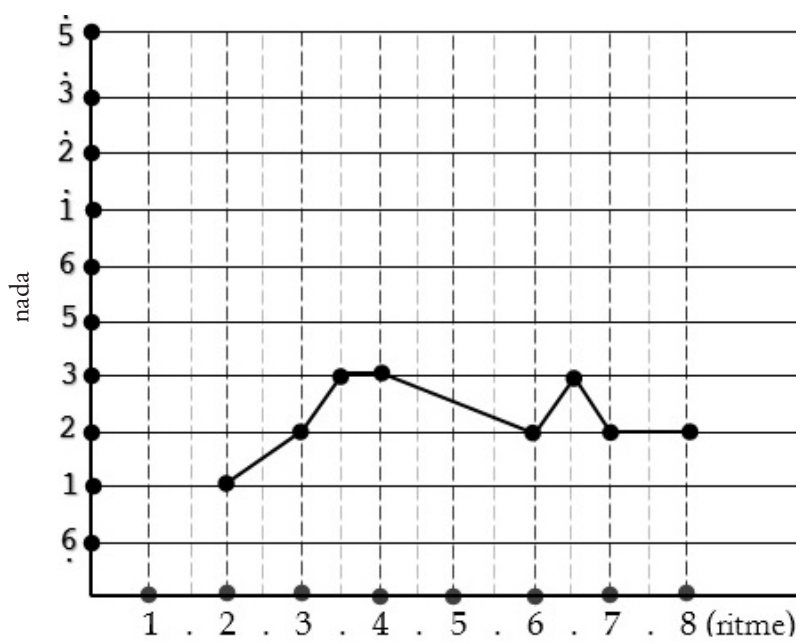

Grafik 4. Alur melodi céngkok Jarik Kawung.

Céngkok Dua Lolobesar laras sléndro pathet manyura

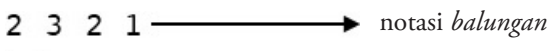

$23221121 \longrightarrow$ tafsir rebaban

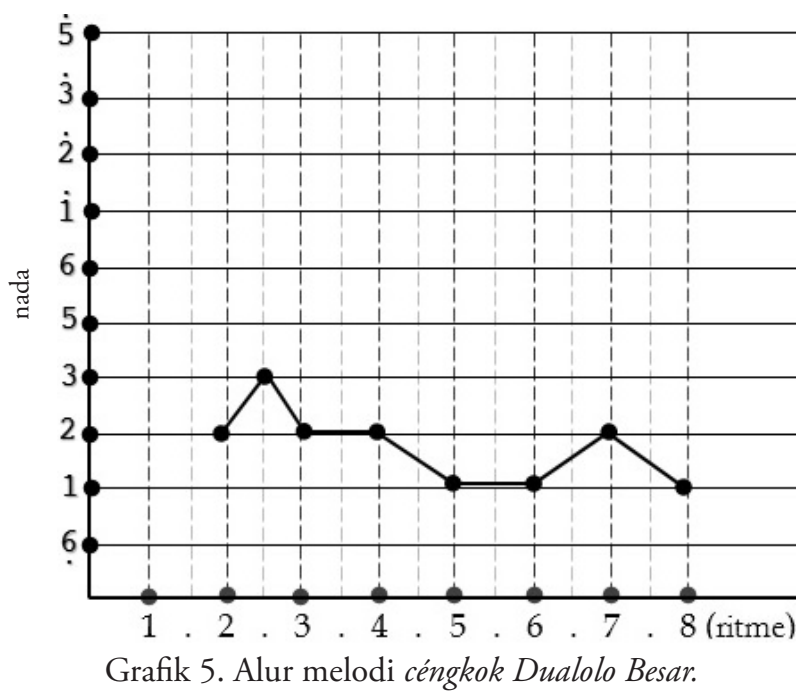


disajikan. Belum ditemukan gending digarap mandheg dengan faktor céngkok semi statis. Secara alur céngkok semi statis tidak memiliki alur yang signifikan, hanya céngkok sèlèh yang normatif sehingga tidak memiliki alur yang spesifik. Hal tersebut mendasari seorang pengrawit terutama seorang pengendang untuk tidak menggarap mandheg pada variabel céngkok dengan alur semi statis.

Céngkok semi statis tidak mendukung garap gending menjadi dinamis, hanya sebagai céngkok sèlèh yang berifat normatif saja, maka jika gending digarap mandheg pada céngkok semi statis sajian akan tidak menjadi dinamis justru akan terasa terputus, karena céngkok semi statis tidak memiliki alur melodi yang spesifik hanya alur sèlèh biasa.

\section{Céngkok Semi Statis}

Statis diartikan sebuah sesuatu dalam keadaan diam atau tidak mengalami pergerakan. Dan dapat dikatakan bersifat pasif. Céngkok statis merupakan céngkok yang memiliki alur flat atau datar, kasus di dalam gending ditemukan pada céngkok nggantung atau gantungan. Céngkok nggantung hanya memainkan satu nada yang diulang beberapa frasa. Berikut analisis céngkok dengan alur statis/flat.

Céngkok statis dalam penyajian gending tidak dapat digarap mandheg, karena céngkok statis merupakan céngkok yang datar dan tidak memiliki

Céngkok Nggantung 6 laras sléndro pathet manyura

$66 \cdot \longrightarrow$ notasi balungan

$6666 \longrightarrow$ tafsir rebaban

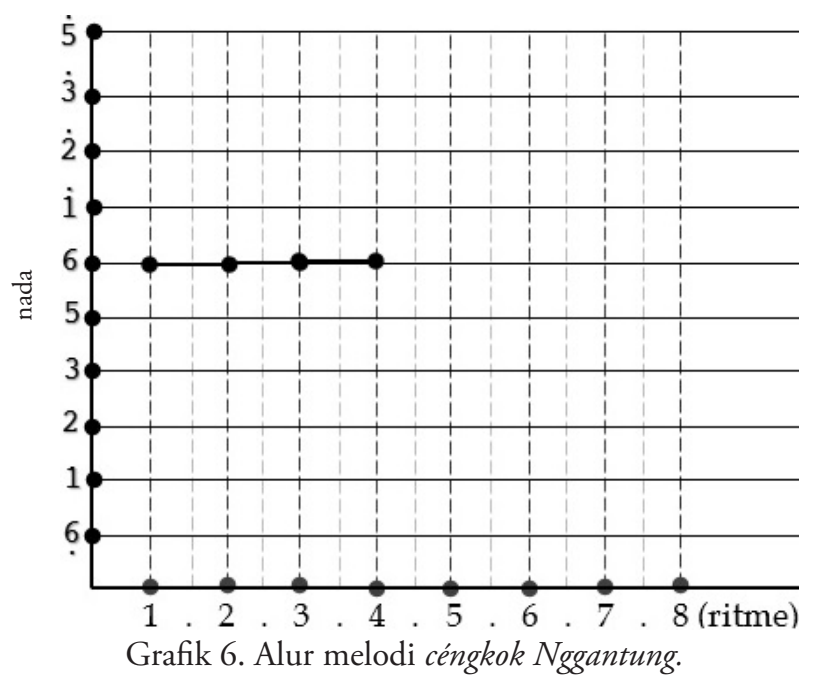

garap yang spesifik, maka jika digarap mandheg sajian akan terputus dan tidak memiliki alur yang spesifik untuk melanjutkan sajian gending.

Berdasar analisis kontur melodi dari beberapa contoh tadi, dapat dirumuskan bahwa seorang pengendang dapat menggarap mandheg sajian gending dengan sebuah acuan jika terdapat céngkok yang memiliki alur dinamis dapat digarap mandheg, dengan letak mandheg yang sudah menjadi konvesional dalam sajian gending.

Céngkok yang memiliki alur dinamis membuat sajian gending menjadi lebih hidup. Céngkok yang memiliki alur semi statis atau statis tidak menutup kemungkinan dapat digarap mandheg, namun céngkok yang cenderung datar akan membuat sajian menjadi terputus ketika digarap mandheg, alur yang tenang atau datar tidak memiliki garap yang spesifik sehingga garap mandheg tidak dapat disajikan.

\section{Penutup}

Mandheg merupakan sebuah garap gending yang di mana gending berhenti sejenak pada sebuah titik, berhenti bukan berarti gending telah selesai, namun hanya berhenti yang bersifat sementara kemudian gending dilanjutkan kembali. Terdapat letak mandheg yang sudah menjadi konvensional dalam setiap truktur gendinya, namun juga terdapat posisi mandheg yang abstrak atau tidak normatif seperti konvensional, hal tersebut dipengaruhi oleh faktor-faktor pembentuk mandheg.

Mandheg dikelompokan menjadi dua yaitu; (1) mandheg kedah dan (2) mandheg pasrèn. Mandheg kedah merupakan sebuah garap mandheg yang penyajiannya diharuskan, karena terikat dengan faktor teks dan lagu yang melekat pada gending. Mandheg kedah memiliki elemen pembentuk andhegan gawan dan kalimat lagu. Gending yang memiliki andhegan gawan wajib disajikan, karena sebagai penciri atau roh dari gending tersebut. Pada kasus kalimat lagu mandheg juga harus disajikan, karena memang sudah diciptakan oleh pengarang gending untuk mandheg di beberapa titik, jika tidak disajikan mandheg maka gending akan rusak atau tidak dapat dilanjutkan kembali. Mandheg pasrèn merupakan mandheg yang bersifat fakultatif atau tidak wajib disajikan. Meskipun kehadirannya 
tidak wajib, namun gending akan lebih hidup atau dinamis jika garap mandheg disajikan. Elemen pembentuk mandheg pasrèn adalah variabel melodi balungan, di mana terdapat susunan balungan yang memiliki alur dinamis maka dapat digarap mandheg, dengan catatan letak mandhegnya konvensional dalam penyajian gending.

Mandheg digunakan sebagai sebuah penciri gending dan varian garap gending. Penciri gending dengan faktor andhegan gawan yang menekankan teks dan lagu sebagai identitas sebuah gending, andhegan gawan bersifat eksklusif, artinya setiap gending memiliki andhegan gawan yang berbedabeda. Mandheg sebagai varian garap digunakan untuk menampilkan kepandaian seorang pesinden secara garap maupun olah vokal. Mandheg juga memiliki fungsi sebagai pembentuk dinamis dalam sajian gending sehingga tidak monoton.

\section{Kepustakaan}

Atmodjo, P. (1987). Kamus Bahasa Jawa (Bausastra Jawa). Surabaya: Djojo Bojo.

Atmojo, B. S. (2010). Kendhangan Pamijen Gending Gaya Yogyakarta. Resital: Jurnal Seni Pertunjukan, 11(1).

Budi Prasetya, H. (2012). Pathêt: Ruang Bunyi dalam Karawitan Gaya Yogyakarta. Panggung: Jurnal Seni \& Budaya, 22(1).

Budiarti, M. (2013). Konsep Kepesindenan dan Elemen-Elemen Dasarnya. Harmonia: Journal of Arts Research and Education, 13(2), 147156.

Darmasti. (2011). Kidung Kandhasanyata Sebagai Ekspresi Estetik Pesinden Wanita Mardusari. Harmonia: Journal of Arts Research and Education, 11(2).

Hastanto, S. (2009). Konsep Pathet dalam Karawitan Jawa. Surakarta: ISI Press.

Hastanto, S. (2012). Konsep Êmbat dalam Karawitan Jawa. Panggung: Jurnal Seni \& Budaya, 22(3).

Irawati, E. (2016). Transmisi Kelentangan dalam Masyarakat Dayak Benuaq. Resital: Jurnal Seni Pertunjukan, 17, 1-25.

Lestariningsih, S. (2016). Makna Dan Implikasi Keteg Di Dalam Garap Gending. Tesis Program
Studi Pengkajian Seni Minat Musik ISI Surakarta, Surakarta.

Martopangrawit. (1969). Pengetahuan Karawitan I. Surakarta: Dewan Mahasiswa Akademi Seni Karawitan Indonesia.

Nursulistiyo, E. (2019). Pemanfaatan Siter, Kendang, Saron, Kenong, dan Gender sebagai media pembelajaran fisika. Jurnal Riset dan Kajian Pendidikan Fisika, 6(1), 5.

Prasetya, H. B., Haryono, T., \& Simatupang, L. L. (2016). Habitus, Ngêng, dan Estetika Bunyi Mlèsèt dan Nggandhul pada Karawitan. Paradigma: Jurnal Kajian Budaya, 1(2), 152.

Rahayu, S. (2018). Estetika Wangsaan dalam Lagu Sindhenan Karawitan Jawa. Gelar : Jurnal Seni Budaya, 16(1).

Saraswati, B. A. (2013). Perjalanan hidup dan kreatifitas sang pesindhèn. Dewa Ruci, 8(2), 157-177.

Setyawan, S. (2018). Kendangan Pinantut dalam Sajian Klenengan. Gelar: Jurnal Seni Budaya, 16(1).

Subuh, S. (2016). Garap Gending Sekaten Keraton Yogyakarta. Resital: Jurnal Seni Pertunjukan, 17(3), 178-188.

Sugimin. (2005). Pangkur Paripurna (Kajian Perkembangan Garap Musikal). Sekolah Tinggi

Seni Indonesia Surakarta, Surakarta.

Sugimin. (2013). Aneka Garap Ladrang Pangkur. Keteg: Jurnal Pengetahuan, Pemikiran dan Kajian Tentang "Bunyi," 13(aneka garap ladrang pangkur), 88-122.

Supanggah, R. (2009). Bothekan Karawitan II: Garap. Surakarta: ISI Press.

Suraji. (2005). Sindhenan Gaya Surakarta. Tesis Program Studi Pengkajian Seni Minat Musik STSI Surakarta, Surakarta.

Surya Osada, S. (2015). Etnomatematika Dalam Titi Laras Dan Irama Pada Karawitan Jawa. Prosiding Seminar Nasional Etnomatnesia, 475-481.

Suyoto. (2016a). Carem: Puncak Kualitas Bawa Dalam Karawitan Gaya Surakarta. UGM, Yogyakarta.

Suyoto. (2016b). Sukon Wulon dalam Tembang Macapat: Studi Kasus Tembang Asmaradana. Keteg: Jurnal Pengetahuan, Pemikiran dan 
Kajian Tentang "Bunyi," 16(1).

Suyoto, Timbul Haryono, S. H. (2015). Estetika

Bawa dalam Karawitan Gaya Surakarta.

Resital: Jurnal Seni Pertunjukan, 16(1), 36-51.

Teguh. (2017). Ladrang Sobrang Laras Slendro

Patet Nem. Resital: Jurnal Seni Pertunjukan, 18(2), 103-112.

Yasa, I. K. (2017). Aspek Musikologis Gêndér

Wayang dalam Karawitan Bali. Resital: Jurnal

Seni Pertunjukan, 17(1).

\section{Diskografi}

Atmosoenarto. 1991. Onang-onang. (Pita kaset). ACD-014. Lokananta Recording.

Soekarno. tt. Budheng-budheng. (Pita kaset). ACD093. Lokananta Recording.

Atmosunarto. 1991. Gambirsawit. (Pita kaset). ACD-101. Lokananta Recording.

Soekarno.1983. Bontit. (Pita kaset). ACD-103. Lokananta Recording.

Atmosunarto. tt. Rujak Sentul. (Pita kaset). ACD058. Lokananta Recording.

Supanggah, Rahayu. 1983. Aneka Jineman Volume 1. (Pita kaset). ACD-239. Lokananta Recording.

Sardiman. 1990. Aneka Jineman. (Pita kaset). KGD-196. Kusuma Record.

\section{Informan}

Suyadi Tedja Pangrawit (72), spesial penyaji ricikan rebab dan kendhang. Empu karawitan gaya Surakarta, pensiunan pengrawit RRI Surakarta. Jurug, Ngringo, Jaten, Karanganyar. Suwito Radyo (62), Empu karawitan gaya Surakarta, spesial penyaji ricikan kendhang, tindhih Abdi Dalem Pengrawit Kasunanan Surakarta, pimpinan kelompok karawitan Cahya Laras. Klaten. Sraten Rt2/5, Trunuh, Klaten Selatan, Klaten.

Sukamso (61), spesial penyaji ricikan gendèr, dosen Jurusan Karawitan, aktif dalam mengikuti kegiatan klenèngan Pujangga Laras. Benowo Rt 006/008, Ngringo, Jaten, Karanganyar.

Purnomo (43), pengendang wayang dan praktisi karawitan Surakarta. Sabrang Lor RT 01 RW 28, Mojosongo, Surakarta.

Tugini (75), spesial penyaji vokal sinden. Pesinden Ki Narto Sabdo. Jl. Jambu No. 62 RT4/6, Jajar, Laweyan, Surakarta.

Suraji (58), dosen Jurusan Karawitan dan praktisi karawitan. Benowo RT 06/VIII, Ngringo, Jaten, Karanganyar.

Bambang Sosodoro R.J. (37), Seniman Karawitan dan Dosen Jurusan Karawitan. Ngemplak RT. 01 RW. 29, Mojosongo, Jebres, Surakarta. 